Nama:Audi pratama

Kelas:HTN f

Nim:10200120225

Tugas:Hukum tatanegara

(Resume )

\title{
A.PARTAI POLITIK
}

1.terbentuknya partai politik

Menurut lapalombara dan weiner,terdapat tiga teori yang menjelaskan asal mula terbentuknya partai politik yaitu:

-teori kelembagaan,yang melihat adanya hubungan antara parlemen awal dengan timbulnya partai politik

-teori situasi historik yang melihat timbulnya partai politik sebagai upaya suatu sistem politik untuk mengatasi krisis yang ditimbulkan dengan perubahan masyarakat secara luas

-teori pembangunan yang melihat partai politik sebagai produk modernisasi sosial ekonomi

\section{Pengertian partai politik}

Partai politik merupakan bagian dari infrastruktur"politik dalam negara.berikut ini pengertian dari partai politik yang dikemukan oleh para ahli:

-miriam budiadjo menyebutkan bahwa partai politik adalah suatu kelompok yang terogrnisir yang anggota-anggotanya memiliki orientasi,nilai-nilai dan cita-cita yag sama.tujuan kelompok ini ialah untuk memperoleh kekuasaan politik dan merebut kedudukan politik,biasanya dengan cara konstitusional,untuk melaksanakan kebijakan-kebijakan mereka

-Sigmund neumann dalam modern political parties mengemukakan definisi sebagai berikut: a political party is the articulate organization of society 's active political agents, those who are concerned with the control of government power and who compete for popular support with another group or groups holdinng divergent views(partai politik adalah organisasi dari aktivis-aktivis politik yang berusaha untuk menguasai kekuasaan pemerintahan serta merebut dukungan rakyat atas dasar persaingan dengan suatu golongan atau golongan-golongan lain yang mempunyai pandangan yang berbeda)

-carl j.friedrich :A political party is a group of human beings,stably organized with the objective of securing or maintaining for its leaders the control of a government,with the further objective of giving to members of the party,through such control ideal and material benefits and adventages(partai politik adalah sekelompok manusia yang teroganisir secara stabil dengan tujuan merebut atau mempertahankan kekuasaan terhadap pemerintahan bagi pimpinan partainya dan berdasarkan penguasaan ini memberikan kepada anggota partainya kemanfaatan yang bdrsifat ideal maupun materiil. 
-r.h soltau mendefinisikan mengenai partai politik adalah a group of citizens more or less organised,who act as a political unit and who by the use of their voting power,aim to control the government and carry out their general

policies.(sekelompok warga kurang lebih terorganisir ,yang bertindak sebagai unit politik dengan menggunakan hak suara mereka,bertujuan untuk mengontrol pemerintah dan melaksanakan kebijakan umum mereka) -robert k.carr:political party isn an organization that attemps to achieve and maintain control of government(partai politik adalah suatu organisasi yang berusaha untuk menncapai dan memelihara pengawasan terhadap pemerintah)

\section{3.fungsi partai politik}

Partai politik telah menjadi ciri penting dalam sebuah politik modern karena memiliki fungsi yang strategis.para ahli pun banyak yang merumuskan fungsi-fungsi partai politik.fungsi utama dari partai politik ialah mencari kekuasaan,mendapat kekuasaan dan mempertahankannya.cara partai politik untuk memperoleh kekuasaan tersebut ialah berpartisipasi dalam pemilihan umum.untuk melaksanakan fungsi tersebut partai politik melakukan tiga hal yang umumnya dilakukan oleh partai politik yaitu menyeleksi calon-calon,setelah calon -calon mereka terpilih selanjutnya ialah melakukan kampanye,setelah kampanye dilaksanakan dan calon terpilih dalam pilihan umum selanjutnya yang dilakukan oleh partai politik ialah melaksanakan fungsi pemerintahan(legistlatif dan eksekutif).

Firmanzah menyebutkan bahwa peran dan fungsi politik dibedakan menjadi dua,yaitu fungsi internal dan fungsi eksternal.dalam fungsi internal ,partai politik berperan dalam pembinaan, pendidikan, pembekalan,dan pengkaderan bagi anggota partai politik demi langgengnya ideologi politik yang menjadi latar belakang pendirian partai politik tersebut.sedangkan dalam fungsi eksternal peranan partai politik terkait dengan ruang lingkup yang lebih luas yakni masyarakat,bangsa,dan negara.hal ini karena partai politik juga mempunyai tanggung jawab konstitusional,moral,dan etika untuk membawa kondisi ,dan situasi masyarakat menjadi lebih baik.

Secara lebih rinci miriam budhardjo menyebutkan bahwa fungsi partai politik adalah: -sarana komunikasi politik

-sarana sosialisasi politik

-rekrutmen politik

-mengatur konflik

\section{Tipologi partai politik}

Tipologi partai politik berkembang seiring dengan perkembangan demokrasi dan kedewasaan masyarakat dalam berpolitik.

Tipologi partai politik dibedakan berdasarkan beberapa klarifikasi,antara lain:

a.Asas dan orientasi

berdasarkan asas dan orientasinya,partai politik dibedakan atas tiga jenis,yaitu partai pragmatis, partai politik doktriner,dan partai politik kepentingan. 


\section{b.berdasarkan komposisi dan fungsi anggotanya}

berdasarkan komposisi dan fungsi anggotanya ini,partai politik dibedakan menjadi partai massa/lindungan dan partai kader serta partai catch-all.

c.berdasarkan kemungkinan memenangkan pemilu

berdasarkan klarifikasi ini,partai politik dibedakan menjadi 2 yaitu partai mayoritas dan partai minoritas.

\section{Visi dan misi partai politik}

Partai politik yang dirikan untuk menfasilitasi kepentingan politik suatu kelompok masyarakat sehingga memberikan kejelasan institusinal atas perjuangan dan aspirasi mereka.jadi pendirian partai politik didahului oleh oleh visi yaang jelas tentanmg mengapa partai politik dibentuk.Pernyataan visi ini juga terkait dengan nilai dan moral idioloigi yang dianutnya serta memberikan landasan bagi perjuangannya.sedangkan misi partai adalah tujuan jangka pendek dan tujuan panjang partai politik.misi adalah mengenal kondisi dan situasi masyarakat edial yang ingin diciptakan oleh partai politik .kejelasan tujuan jengka pendek dan jangka panjang ini juga akan membantu bagi penyusunan tujuan antara maupun strategis untuk mencapainya.

\section{B.SISTEM PEMILIHAN UMUM}

\section{1.makna pemilihan umum}

Pemilihan umum adalah sarana pelaksanaan kedaulatan rakyatnyanmg diselenggarakan secara langsung,umum, bebas,rahasia,jujur,dan adil dalam negara kesatuan republik indonesia berdasarkan pancasila dan undang-undan $\mathrm{g}$ dasar negara republik indonesia tahun 1945.atau secara ringkas dikemukakan oleh harmaily ibrahim bahwa,pemilu merupakan suatu cara untuk menentukan wakil-wakil rakyat yang akan duduk dibadan perwakilan rakyat.Dengan demikian,pemilu pada hakikatnya merupakan wahana untuk berkompetisi secara sehat,partisipasi,dinamis, dan bertanggung jawab bagi partai politik(parpol)dalam menyalurkan kehendak rakyat ,masyarakat dan bangsa guna mewujudkan tujuan bernegara.

Menurut saragih(1997)pemilu dapat digolongkan dalam dua hal pokok ,yaitu:

a).adalah bagaimana melaksanakan sistem yang sudah ada aturan-aturannya secara umum(diakui dan dianut oleh umumnya negara-negara emokrasi konstitusional),hal ini sering disebut electoral law yang mengatur sistem pemilu dan aturan yang menata bagaimana pemilu dijalankan, bagimana distribusi hasil pemilu ditetapkan dan seterusnya.

b).adalah bagaimana mekanisme pelaksanaan suatu pemilu,yang biasanya disebut electoral process, ini ditentukan misalnya siapa panitia penyelenggara pemilu,partai/organisasi peserta pemilu, penentuan calon-calon,cara dan tempat berkampanye,kotak suara,jumlah TPS,saksi,perpindahan pemilih dan sebagainya. 


\section{2.tujuan pemilihan umum}

Berdasarkan pada peraturanperundang-undangan yang mengatur tentang pemilu -hukum pemilihan umum,didefinisikan tujuan pemilu,Sebagai berikut;

a.memilih wakil rakyat yang akan duduk dilembaga perwakilan/permusyawaratan rakyat:memilih anggota-anggota DPR,DPD, dan DPRD

b.membentuk pemerintahan:memilih calon presiden dan wakil presidan,memilih calon kepala daerah

c.melanjutkan perjuangan mengisi kemerdekaan

d.mempertahankan keutuhan negara

e.menegakkan kedaulatan rakyat

f.mencapai tujuan negara

sedangkan menurut J.kristiadi mengemukakan fungsi pemilu sebagai berikut:

a.institusi dan instrumen untuk mengendalikan konflik-konflik kepentingan yang terjadi dalam masyarakat.

b.sarana untuk pergantian pemerintahan secara wajar dan damai.

c.untuk membangun basis legitimasi politik konstitusional.

d.untuk mengetahui tingkat kedewasaan dan kemantapan budaya politik nasional.

e.untuk memperoleh banyak informasi tentang berbagai kebijakan dan

permasalahan yang dihadapi bangsa dan negara dalam mewujudkan kesejahteraan warganya.

3.menurut ramlan surbakti,sistem pemilu yang ideal diharapkan dapat menghasilkan tatanan politik sebagai berikut:

a)lembaga perwakilan yang mencerminkan keterwakilan penduduk dan keterwakilan daerah secara adil dan efektif,tidak hanya keterwakilan dalam gagasan tetapi juga ketewakilan dalam kehadiran.

b).keterwakilan dalam kehadiran berbagai kelompok "minoritas"dalam lembaga perwakilan dipusat dan daerah yang melalui proses pemilihan tidak terwakili(unrepresented)atau kurang terwakili(underrepresented).

c).anggota lembaga perwakil yang lebih tampil sebagai wakil rakyat daripada wakil partai

d).wakil rakyat yang tidak saja mendapat legitimasi tinggi dari rakyat tetapi juga memiliki kredibiltas(integritas dan kemampuan)

e).wakil rakyat akuntable kepada konstituennya yang mempunyai akses luas untuk mempengaruhi wakil rakyat. 
f).wakil rakyat yang mempunyai kemampuan lebih mengedepankan dalam fungsi legislasi dan anggaran dari pada dalam fungsi pengawasan.

g).proses politik yang dinamis tetapi relatif mudah mencapai kesepakatan lembaga legislatif

h).pemindahan perbedaan anspirasi,bahkan konflik kepentingan masyarakat ke dalam lembaga penyelenggaraan negara ,seperti lembaga perwakilan rakyat.

i).pemerintah yang kuat dan stabil karena didukung suara mayoritas dan oposisi yang memiliki keberdayaan dalam lembaga legislatif.

j).jumlahb partai politik peserta pemilu yang tidak terlalu sedikit tetapi juga tidak terlalu banyak dengan jarak ideologi yang tidak terlalu jauh(sistem kepartaian pluralisme moderat).

k).partai politik dan politisi yang bersifat insklusif dan mampu bekerja sama dengan cara menghilangkan eksklustifisme partai politi/politisi.

L)menghasilkan perilaku pemilih yang lebih mengambarkan citizen politic(perilaku memilih individu warga negara rasional dan transaksional)dengan menghilangkan mass politics(politik massa,perilaku pemilih memilih massa yang fanataik berdasarkan simbol-simbol personal)

m)perubahan politik secara periodik baik berupa sirkulasi elit maupun berupa perubahan arah pola kebijakan publik.

n).isu-isu politik lokal mempunyai kesempatan yang sama dengan isu-isu politik nasional untuk menjadi isu publik.

4.asas -asas pelaksanaan pemilihan umum

Asas 22E ayat(1)UUD 1945 menentukan bahwa,pemilihan umum, dilaksanakan secara langsung,umum,bebas,rahasia,jujur,dan adil setiap lima tahun sekali.pasal 2 UU no.42 tahun 2008(pilpres)menentukan bahwa ,pemilu presiden dan wakil presiden dilaksanakan secara efektif dan efisien berdasarkan asas langsung,umum, bebas, rahasia,jujur dan adil.pasal 2 UU no.8 tahun 2015 (pemilukada)menentukan bahwa ,pemilihan dilaksanakansecara demokratis berdasarkan asas langsung,umum,bebas,rahasia,jujur,dan adil.dengan demikian,asas pemilu untuk penyelenggaraan pileg,,pilpres dan pemilukada sama yaitu dilaksanakan secara langsung,umum, bebas, rahasia,jujur,dan adil. Dalam pasal 22E UUD 1945 tidak ada penjelasan mengenai asas-asas pemilu tersebut.demikian pula dalam UU no 42 tahun 2015. 
Penjelasan asas-asas tersebut terdapat dalam penjelasan umum UU No .8 tahun 2012.asas langsung maksudnya bahwa,rakyat seabagai pemilih mempunyai hak untuk memberikan suaranya secara langsung sesuai dengan kehendak hati nuraninya ,tanpa perantara.pemilihan yang bersifat umum mengandung makna menjamin kesempatan yang berlaku menyeluruh bagi semua warga negara,tanpadiskriminasi berdasarkan suku,agama,ras,golongan,jenis kelamin,kedaerahan,pekerjaandan status sosial.setiap warga negara berhak memilih bebas menentukan pilihannya tanpa tekanan dan paksaan dari siapa pun.didalam melaksanakan haknya,setiap warga negara dijamin keamanannya oleh negara,sehingga dapat memilih sesuai dengan kehendak hati nurani.dalam memberikan suaranya,pemilih dijamin bahwa pioleh pihak manapun.pemilih memberikan suaranya pada surat suara dengan tidak dapat diketahui oleh orang lain.dalam penyelenggaraan pemilu ini,penyelenggara pemilu,aparat pemerintah, peserta pemilu,pengawas pemilu,pemantau pemilu ,pemilih,serta semua pihak yang terkait harus bersikap dan bertindak jujur sesuai dengan ketentuan peraturan perundang-undangan.setiap pemilih dan peserta pemilu mendapat perlakuan yang sama,serta bebas dari kecurangan pihak manapun. 